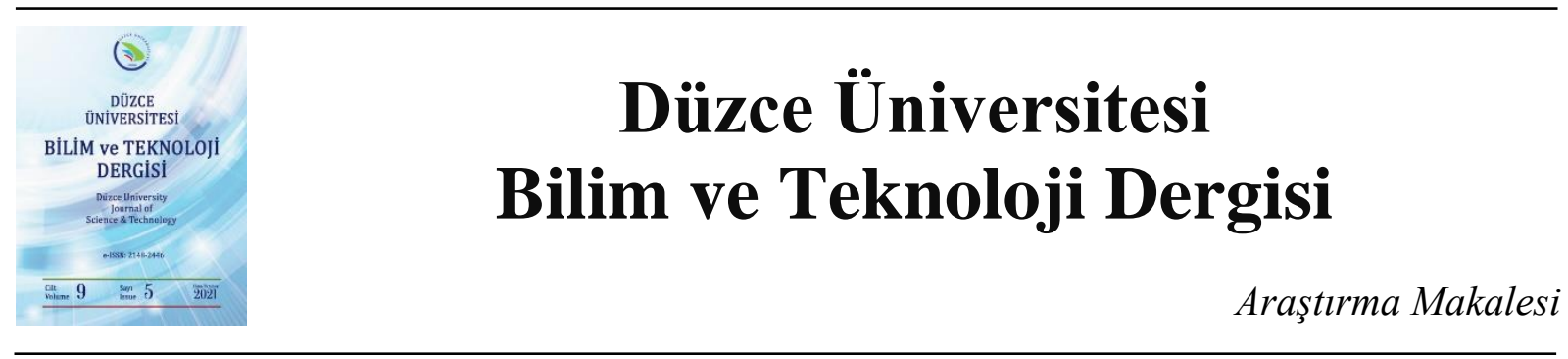

\section{Biyodizel ve EGR Kullanılan Bir Dizel Motorunda Motor Performansını ve NO Emisyonunu Etkileyen Faktörlerin Taguchi Yöntemi ile Optimizasyonu}

\author{
(i) Çiçek ÇANGAL ${ }^{\mathrm{a}, *}$, (D) Vezir AYHAN ${ }^{\mathrm{a}}$ \\ ${ }^{a}$ Makine Mühendisliği Bölümü, Lisansüstü Eğitim Enstitüsü, Sakarya Uygulamalı Bilimler Üniversitesi, \\ Sakarya, TÜRKIYE \\ * Sorumlu yazarın e-posta adresi: cicek_ceyhan@hotmail.com
}

DOI: 10.29130/dubited.700971

\begin{abstract}
$\ddot{\mathrm{O} Z}$
Araç motorlarında petrol kökenli yakıtlara bağımlı kalındığı sürece çevre kirliliğinin tehlikeli boyutlara ulaşması yadsınamaz bir gerçektir. Ayrıca fosil yakıt kaynaklarının azalması farklı yakıt arayışlarını zorunlu hale getirmiştir. Dolayısıyla günümüzde alternatif yakıtları geliştirme çabaları ve bu yakıtların araç motorlarında kullanılması yaygınlaşmaktadır. Bunun yanı sıra egzoz emisyon standartlarındaki kısıtlayıcı yasalar gereği yenilenebilir alternatif yakıtlarla birlikte emisyon azaltıcı yöntemlerin de kullanılması gereklidir. Bu amaçla bu çalışmada, tek silindirli direkt püskürtmeli ve tam yükte çalışan bir dizel motoruna farklı oranlarda biyodizel (B10, B20 ve B50) ve egzoz gaz1 resirkülasyonu (EGR) (\%10, \%15 ve \%20) uygulanarak motor performans ve NO emisyonlarındaki değişimler deneysel olarak araştırılmıştır. Deney tasarımının Taguchi optimizasyon yöntemi ile yapıldığı çalışmada L16 ortogonal dizisi kullanılmış, böylece deneyler esnasında zaman ve maliyetten tasarruf edilerek motor performansı ve NO emisyonunun optimizasyonu yapılmıştır. Motor performansı ve NO emisyonu üzerinde etkili faktörler olarak biyodizel, EGR ve devir seçilmiş ve bu faktörlerin farklı seviyeleri kullanılmıştır. Sinyal/Gürültü $(\mathrm{S} / \mathrm{N})$ analizi sonucunda motor parametreleri açısından en iyi kombinasyonlar belirlenmiştir. Daha sonra faktörlerin etki dereceleri ANOVA (varyans) analizi ile test edilmiştir. Son olarak doğrulama deneyleri yapılmış ve Taguchi optimizasyonu sonucu elde edilen iyileşmeler standart motor sonuçlarıyla karşılaştırmalı olarak verilmiştir. Motor döndürme momenti ve özgül yakıt sarfiyatı (ÖYS) açısından optimum sonuçlar B20 yakıtında, EGR uygulanmadiğında (EGR0) ve $1600 \mathrm{~d} / \mathrm{d}$ 'da elde edilmiştir. Taguchi optimizasyonu sonucu momentte \%1,11'lik, ÖYS'de ise \%0,67'lik bir iyileşme kaydedilmiştir. NO emisyonunda ise Taguchi optimizasyonu sonucunda \%92,3'lük bir iyileşme meydana gelmiştir. ANOVA analizi sonucunda faktörlerin performans parametreleri üzerinde \%99 ile \%99,99 arasında etkili oldukları saptanmıştır.
\end{abstract}

Anahtar Kelimeler: Biyodizel, EGR, Taguchi optimizasyonu, motor performansı, NO emisyon

\section{Optimization of Factors Affecting Engine Performance and NO Emissions in a Diesel Engine Using Biodiesel and EGR by Taguchi Method}

\section{ABSTRACT}

It is an undeniable fact that environmental pollution reaches dangerous levels as long as the use of petroleumbased fuels in vehicle engines. In addition, the decrease in fossil fuel resources has made it necessary to search 
for different fuels. Therefore, efforts to develop alternative fuels and the use of these fuels in vehicle engines are becoming widespread today. In addition, in accordance with the restrictive laws in the exhaust emission standards, emission reduction methods should be used together with renewable alternative fuels. For this purpose, in this study, changes in engine performance and $\mathrm{NO}$ emissions were investigated by applying different rates of biodiesel (B10, B20 and B50) and exhaust gas recirculation (EGR) (10\%, 15\% and 20\%) to a single cylinder direct injection diesel engine operating at full load. The L16 orthogonal sequence was used in the study where the experimental design was made with Taguchi optimization method, thus optimization of engine performance and NO emission was performed by saving time and cost during the experiments. Biodiesel, EGR and speed were selected as factors affecting engine performance and NO emission, and different levels of these factors were used. As a result of Signal/Noise $(\mathrm{S} / \mathrm{N})$ analysis, the best combinations in terms of engine parameters were determined. Then, the effect degrees of the factors were tested by ANOVA (variance) analysis. Finally, validation experiments were conducted and improvements obtained as a result of Taguchi optimization were given in comparison with standard engine results. Optimum results in terms of engine torque and brake specific fuel consumption (BSFC) were obtained in B20 fuel, when EGR is not applied (EGR0) and at $1600 \mathrm{rpm}$. As a result of Taguchi optimization, an improvement of $1.11 \%$ in moment and $0.67 \%$ in BSFC was recorded. An improvement of $92.3 \%$ was achieved in NO emission as a result of Taguchi optimization. As a result of ANOVA analysis, factors were found to be effective between $99 \%$ and $99.99 \%$ on performance parameters.

Keywords: Biodiesel, EGR, Taguchi optimization, engine performance, NO emission

\section{GIRIS}

Dünya üzerinde bulunan ve gittikçe azalan fosil yakıtlar, enerji üretimi için gerekli olan kaynakların başında gelir. Bu yakıtların, azalmasının yanı sıra küresel ısınmayı artırması ve zararlı emisyonlara neden olması gibi olumsuzlukları da vardır. Bu nedenle, bitkisel yağların yenilenebilir ve biyolojik olarak parçalanabilir olması, toksik madde içermemesi ve NOx haricinde düşük emisyon profillerine sahip olması dizel motorlarındaki kullanımını yaygınlaştırmaktadır [1]. Böylece bitkisel yağların dizel motorlarında kullanılması büyük önem teşkil etmektedir [2]. Bitkisel yağlar ayçiçek, mısır, pamuk, gibi farklı bitkilerden elde edilebilmektedir [3]. Bunun yanı sıra, petrol kökenli yakıtların kullanımının azaltılması, emisyon standartlarına getirilen kısıtlamalar nedeniyle zorunlu hale gelmiştir. Özellikle en son yürürlüğe giren Euro 6 emisyon standardı ile egzoz emisyonlarının çevreye verdiği zararın büyük oranda azaltılması hedeflenmektedir. Petrolden elde edilen yakıtların yanı sira standart dizel motorunda biyodizel yakıt kullanıldığında, biyodizelin oksijen içermesi ve dizel yakıta göre hava fazlalık katsayısının daha düşük olmasından dolayı NOx emisyonu dizel yakıt ile çalışan standart motora göre artma eğilimindedir [4]. Dolayısıyla NOx salınımını azaltmak için bazı yöntemler geliştirilmiştir. Bu yöntemlerden en etkilisi EGR sistemidir. Bu sistem egzoz gazlarının bir bölümünün silindire geri verilmesini sağlayarak, karışımın içerdiği oksijen miktarını azaltıp, karışım oranını düşürmek ve silindir içerisindeki gazların 1sı kapasitesinin artmasını sağlayarak gaz sıcaklığını düşürmektir. Silindire geri verilen egzoz gazları sayesinde yanma odasındaki karışım seyreltilerek yanma sonu sıcaklığı ve buna bağlı olarak üretilen NOx miktarı azaltılmaktadır [5-7].

Biyodizel ile yapılan deneysel çalışmalar incelendiğinde biyodizelin motor performansı ve bazı emisyonlar açısından olumlu sonuçlar verdiği saptanmıştır. Bu durum biyodizelin dizel motorlarında alternatif ve sürdürülebilir bir yakıt olduğunu göstermektedir [8-10]. Ayhan vd. [10] direkt püskürtmeli bir dizel motorunda yaptıkları deneysel çalışmada farklı oranlarda ayçiçek yağı metil esteri kullanmışlardır. Moment ve efektif güç açısından en iyi biyodizel oranının B20 olduğunu tespit etmişlerdir. Yakıt içerisindeki biyodizel miktarı az olduğunda ÖYS'nin azaldığını, efektif verimin ise arttığını saptamışlardır. B50 yakıtında ise ÖYS ve efektif verimin kötüleştiği sonucuna ulaşmışlardır. Standart durumda $1300 \mathrm{~d} / \mathrm{d}$ motor devrinde $61,6 \mathrm{Nm}$ olarak ölçülen motor tork değeri, B10 kullanımında $61,7 \mathrm{Nm}$ ve B20 kullanımında ise $62,1 \mathrm{Nm}$ ve B50'de ise $61,2 \mathrm{Nm}$ olarak ölçülmüştür. Standart durumda $2200 \mathrm{~d} / \mathrm{d}$ motor hızında maksimum 12,42 kW olarak ölçülen efektif güç değeri B10' da $12,45 \mathrm{~kW}$, B20' de 12,5 kW, B50 kullanımında ise 12,4 olduğu tespit edilmiştir. NO emisyonlarının ise biyodizel kullanımı ile artığını saptamışlardır. Keskin vd. [11] mısır yağı biyodizeli kullanarak yaptıkları deneysel çalışmada, motor momenti ve motor gücünde kayda değer bir değişimin olmadığını tespit etmişlerdir. Özgül yakıt tüketiminde ise biyodizelin artışa sebebiyet verdiğini 
gözlemlemişlerdir. Araştırmacılara göre mısır yağı biyodizelinin alt 1sıl değeri dizel yakıta oranla düşük olduğundan, biyodizel kullanılan çalışmalarda özgül yakıt tüketiminde artma olmaktadır. Biyodizel kullanımı ile CO ve is emisyonlarının azaldığını, NOx emisyonlarının ise arttığını saptamışlardır. Karabaş [1] tek silindirli, su soğutmalı bir dizel motorunda tütün tohumu yağı biyodizeli kullanarak motorun performans ve emisyonlarındaki değişimlerini deneysel çalışma yaparak incelemiştir. Tam yük koşullarında ve $\% 10, \% 20, \% 50$ ve $\% 100$ kütlesel biyodizel oranlarında gerçekleştirilen deneylerin sonuçlarını standart motor verileri ile karşılaştırmıştır. B10, B20 ve B50 karışımları ile yaptığı deneyler sonucu dizel yakıta göre daha yüksek motor gücü ve motor momenti tespit etmiştir. B100 yakıtı kullanıldığında ise moment ve güçte azalmalar gözlemlemiştir. B10, B20, B50 ve B100 kullanımı ile ve yakıt içerisindeki biyodizel oranı arttıkça NOx emisyonlarının artış gösterdiğini, $\mathrm{HC}, \mathrm{CO}$ ve is emisyonlarının ise azaldığını saptamıştır. Rosha vd. [12] sıkıştırma ateşlemeli bir dizel motorda yakıt olarak \%20 palm biyodizeli kullanarak farklı sıkıştırma oranlarında motor karakteristiklerini incelemişlerdir. Sonuç olarak B20 yakıtının yüksek motor sıkıştırma oranında motor performansı açısından iyi bir sonuç verdiğini saptamışlardır. Raman vd. [13] dört zamanl1, tek silindirli direkt enjeksiyonlu bir dizel motorda, kolza yağı biyodizeli (B100) ve dizel-biyodizel karışımlarının (B25, B50, B75) 200 bar sabit enjeksiyon basıncında motorun performans, yanma ve emisyon özelliklerine etkilerini analiz etmek için deneyler yapmışlardır. Deney sonucunda, B100 yakıtı ve diğer biyodizel karışımları kullanıldığında motorun ÖYS ve egzoz gazı sıcaklığının arttığını gözlemlemişlerdir. Maksimum silindir basıncı biyodizelde dizel yakıtlı motora göre daha düşük tespit edilmiştir. Biyodizel yakıtlarında $\mathrm{HC}$ ve $\mathrm{CO}$ emisyonlarının dizel yakıta göre daha düşük, $\mathrm{NO}$ ve is emisyonlarının ise daha yüksek olduğunu saptamışlardır.

Dizel motorlarında EGR'nin uygulandığ NOx emisyonunun ise azaldığı görülmektedir [5, 14-16]. Haşimoğlu vd. [5] yapmış oldukları çalışmada dizel motorlarında EGR'nin motor performansı ve egzoz emisyonlarına etkisini deneysel olarak araştırmışlardır. Çalışmalar esnasında farklı oranlarda egzoz gazlarını emme hattına geri göndererek motor performans ve emisyonlarındaki değişimi izlemiş̧lerdir. Deneyler sonucunda EGR uygulamasıyla NOx emisyonlarında kayda değer bir düşüş gözlemlemişlerdir. Standart değerler ile $\% 10$ ve \%20 EGR uygulandığı durumdaki değerler arasında, sırasıyla yaklaşık olarak ortalama \%35 ve \%75'lik bir azalma olmuştur. \%30 EGR durumunda ise emisyon ölçüm cihazında NOx emisyonları sıfır olarak ölçülmüştür. He vd. [17] tek silindirli bir dizel motorunda farklı EGR oranları uygulayarak yapmış oldukları deneysel çalışmada, EGR oranlarının orta seviyelerde seçilmesiyle motor performansının ve emisyonların daha iyi sonuçlar verdiğini gözlemlemişlerdir. Verma vd. [15] çift yakıtlı (dizel-biyogaz) bir dizel motorunda farklı EGR ve sıkıştırma oranlarının motor performans ve emisyonlarındaki etkilerini deneysel çalışmalar yaparak incelemişlerdir. EGR ile düşük yüklerde motor veriminde bir miktar artış ve NOx emisyonlarında azalma tespit etmişlerdir. Yüksek yüklerde ve artan EGR oranlarında ise motor veriminde azalmanın olduğunu gözlemlemişlerdir.

Literatürde dizel motorlarında biyodizel ve EGR'nin birlikte uygulandığı farklı çalışmalar mevcuttur. Ayhan vd. [18] direkt enjeksiyonlu tek silindirli bir dizel motorunda biyodizel ve EGR'nin farkl1 oranlarını kullanarak yapmış oldukları çalışmada biyodizel ve EGR'nin motor performansı ve emisyonlar üzerinde etkili olduklarını tespit etmişlerdir. Motora uygulanan $\% 10, \% 15$ ve \%20 oranlarında EGR ile NOx emisyonlarının azaldığını tespit etmişlerdir. Maksimum azalma \%20 EGR oranında meydana gelmiştir. Bhowmick vd. [19] common rail (tutuculu püskürtme sistemi) direkt enjeksiyonlu bir dizel motorda farklı enjeksiyon stratejileri ve EGR'nin etkilerini araştırmak için deneysel çalışmalar yapmışlardır. Bunun için tamanu (calophyllum inophyllum) biyodizeli üretmişler (CIP10) ve bu yakıtın \%10'luk bir karışımını (CIP10) hazırlamışlardır. Deney sonuçlarına göre CIP10 yakıtı ve P10-M90 yakıt enjeksiyon stratejisi beraber uygulandığında, dizel motora ve diğer enjeksiyon stratejileri ile çalışan motora göre $\mathrm{CO}$ ve $\mathrm{HC}$ emisyonlarında kayda değer bir düşüş gözlemişlerdir. Yine CIP10 P10-M90 ve tam yük durumunda NOx emisyonlarında dizel motora göre $\% 18,9$ oranında artış olduğunu tespit etmişlerdir. CIP10 P10-M90 ile \%10 ve \%20 EGR uygulamasıyla NOx emisyonlarının (motor performansında önemli bir kayıp olmadan) EGR'siz CIP10 P10-M90'a kıyasla sırasıyla \%14,4 ve \%27,6 azalma gösterdiğini gözlemlemişlerdir. Can vd. [20] $2200 \mathrm{~d} / \mathrm{d}$ 'da ve dizel yakıt ile karıştırılmış $\% 20$ soya fasulyesi biyodizel yakıtı ile çalışan tek silindirli direkt enjeksiyonlu bir dizel motorda farklı EGR oranlarını (\%5, \%10, \%15) test etmişlerdir. Motor 
deneylerini dört farklı yük altında $(15,11,25,7,5$ ve $3,75 \mathrm{Nm})$ gerçekleştirmişlerdir. Deney sonuçlarına göre biyodizel ve EGR uygulamasıyla maksimum 1s1 yayılım oranı ve maksimum silindir basıncında artma gözlemlemişlerdir. Bununla birlikte 1sı yayılım oranlarının merkezi ÜÖN'ya kayarken, yanma süreleri genellikle stabil kalmıştır. Genel olarak EGR ile ÖYS'nin arttığını, efektif verimin ise azaldığını saptamışlardır. Biyodizel ve EGR ile NOx ve is emisyonlarını yüksek motor yükünde sırasıyla $\% 55$ ve $\% 15$ oranlarında iyileştirmişlerdir. Shi vd. [21] yapmış oldukları deneysel çalışmada farklı motor yüklerinde çalışan dört silindirli bir dizel motorunda yüksek EGR ve biyodizelin (\%20 soya fasulyesi biyodizeli) yanma ve emisyonlar üzerindeki etkilerini araştırmışlardır. EGR, \%10 ile \%62 oranları arasında uygulanmıştır. Biyodizel yakıt ilavesi ve \%15 EGR oranı kombinasyonu ile NOx emisyonlarındaki iyileştirmeler, yüksek motor yükünde $\% 55$, orta motor yükünde $\% 38$, kısmi motor yükünde $\% 26$ ve düşük motor yükünde $\% 9,94$ 'tür. Biyodizel ile $\% 15$ EGR uygulandığında tüm motor yüklerinde ÖYS bir miktar artmış, efektif verim ise azalmıştır. Yasin vd. [22] dört zamanlı su soğutmalı direkt enjeksiyonlu ve biyodizel (Palm biyodizeli) kullanılan bir dizel motorunda EGR'nin motor performansı ve emisyonlara etkisini incelemişlerdir. Deney sonuçları standart motorla karşılaştırmalı olarak verilmiştir. Buna göre, biyodizel ve EGR kullanıldığında motor gücü, motor momenti ve NOx emisyonlarında düşüş; ÖYS, $\mathrm{CO}$ ve $\mathrm{CO}_{2}$ emisyonlarında az miktar artış gözlemlemişlerdir.

$\mathrm{Bu}$ çalışmanın deney tasarımı, Taguchi’nin önerdiği yöntem ile yapılmıştır. Bu yöntem, deneylerdeki faktörlerin tüm eşleşmelerinin denenmesi yerine ortogonal dizinin oluşturduğu kombinasyonların denenmesi ile optimum performans karakteristiğini veren faktör seviyelerinin tespit edilmesidir [23]. $\mathrm{Bu}$ doğrultuda literatür çalışmaları incelendiğinde zaman ve maliyet kayıplarını azalttığı için Taguchi yönteminin birç̧ok araştırmacı tarafından tercih edildiği görülmektedir [24-26]. Buna istinaden, literatürde motor performans ve emisyonlarının en iyi değerlerini elde etmek için farklı motor parametrelerinin Taguchi yöntemi kullanılarak optimizasyonunun yapıldığ 1 birçok çalışmaya rastlanmıştır [26-28]. Çangal [29] direkt enjeksiyonlu tek silindirli bir dizel motorunda Taguchi yöntemini kullanarak ve faktör olarak yük, motor hızı, biyodizel, etanol, EGR ve aşırı doldurmanın farklı seviyelerini seçerek motor deneyleri yapmıştır. Deneylerde, motor performansı ve egzoz emisyonlarındaki değişimleri incelemiştir. Sonuç olarak hem motor performansı hem de egzoz emisyonları açısından en iyi kombinasyonları \%95 doğruluk oranıyla elde etmiştir. Ansari vd. [30] Taguchi metodunu kullanarak farklı biyodizel karışımları uygulanan bir dizel motorunda motor performans ve emisyonlarının değişimlerini incelemişlerdir. Çalışmada girdi parametreleri, en iyi motor performans ve emisyon değerlerini verecek şekilde optimize edilmiştir. Ayhan vd. [7] bir dizel motorunda farklı oranlarda yakıt püskürtme avansı ve buhar enjeksiyonu değerlerinde motor performans ve emisyonlarında meydana gelen değişimleri incelemişlerdir. Motor performansının ve NOx emisyonunun optimum oldukları faktör ve seviyeleri Taguchi yöntemi ile tespit etmişlerdir. Wu ve $\mathrm{Wu}$ [25] tek silindirli bir dizel motorunda farklı oranlarda biyodizel-dizel karışımı ile $\mathrm{H}_{2}$ kullanarak ve emme manifolduna farklı oranlarda EGR uygulayarak motor emisyonlarını ve yanma performansını incelemiş ve girdi parametrelerinin en iyi kombinasyonlarını Taguchi metoduyla belirlemişlerdir. L9 ortogonal dizisinin kullanıldığı Taguchi deney tasarım yöntemi ile yapılan deneylerde \%67 oranında zamandan tasarruf sağlamışlardır. Wu vd. [24] bir dizel motorunda farklı oranlarda LPG ve biyodizel kullanarak ve motora farklı oranlarda EGR uygulayarak Taguchi yöntemi ile yanma karakteristiklerini incelemiş ve motorun optimum çalışma koşullarını tespit etmişlerdir. Motor $1500 \mathrm{~d} / \mathrm{d}$ 'da ve farklı yüklerde çalışırken en büyük yakıt tüketim süresini, en düşük duman ve $\mathrm{NO}_{\mathrm{x}}$ emisyonlarını elde etmek için az sayıda deney yaparak en uygun çalışma faktörlerini belirlemişlerdir. Balkı vd. [27] dört silindirli, dört zamanlı, hava soğutmalı bir benzin motorunda saf benzin ve metanol-etanol karışımlarının kullanılmasının motor performans ve egzoz emisyonları üzerindeki etkilerini araştırmışlardır. Çalışma faktörlerinin ateşleme zamanı, sıkıştırma oranı ve motor hızı olarak seçildiği çalışmada faktörlerin optimizasyonu için Taguchi deney tasarım yöntemini ve ANOVA analizini kullanmışlardır. Üçer seviyeli üç faktörün motor performans ve emisyonlarına olan etkilerini araştırmak için yapılan çalışmada L9 ortogonal dizisi kullanılmıştır. Optimize edilmiş motordan elde edilen performans değerlerini ve egzoz emisyon değerlerini temel motorun değerleri ile karşılaştırmışlardır. Doğrulama deneyi sonucunda Taguchi yöntemi sayesinde motor testi sayısı \%89 oranında azaltılmış ve yapılan optimizasyon \%95 güven aralığında gerçekleştirilmiştir. Optimize edilmiş motordan, temel motora kıyasla daha iyi sonuçlar elde etmişlerdir. 
$\mathrm{Bu}$ çalışmada, tek silindirli direkt enjeksiyonlu, tam yükte ve farklı devirlerde çalışan bir dizel motorunda farklı oranlarda biyodizel yakıt kullanarak ve motora farklı oranlarda EGR uygulayarak motorun performans ve NO emisyonlarındaki değişimler incelenmiştir. Motor performans parametreleri ve NO emisyonlarının optimum kombinasyonları Taguchi yöntemi ile belirlenmiş ve buna göre deneysel çalışmalar yapılmıştır.

\section{MATERYAL VE YÖNTEM}

\section{A. BIYYODIZEL ÜRETIMI}

Deneysel çalışmalarda dizel ve \%10, \%20, \%50 biyodizel-dizel karışımlı yakıtlar kullanılmıştır. Karışım yakıtlarının elde edilmesi için, biyodizel ve dizel yakıtlar, deneyler öncesinde hassas terazi ile tartılarak kütlesel oranlarda birleştirilmiştir. Biyodizel yakıt, mısır yağından transesterifikasyon yöntemiyle üretilmiştir. Transesterifikasyon, hayvansal ve bitkisel kökenli yağların genellikle metanol ve etanol gibi alkollerle reaksiyona girmesi ile biyodizel üretilmesi yöntemidir. Bu yöntemin diğer biyodizel üretim yöntemlerine göre avantajları arasında yüksek miktarda setan sayısı, yenilenebilir özellik, yüksek yanma verimi ve düşük miktarda emülsiyon içermesi sayılabilir [31]. Deneylerde kullanılan dizel ve biyodizel yakıtların özellikleri Tablo 1'de verilmiştir.

Tablo 1. Deneysel çalışmalarda kullanılan yakttların özellikleri

\begin{tabular}{ccc}
\hline Özellik & Dizel & Biyodizel (Mısır yağı) \\
\hline Yoğunluk $\left(15^{\circ} \mathrm{C}\right)$ & $0,82-0,86$ & $0,87-0,88$ \\
Setan sayısı & 49 & $>55$ \\
Kinematik viskozite $\mathrm{mm}^{2} / \mathrm{s},\left(40^{\circ} \mathrm{C}\right)$ & $2,5-3,5$ & 4,3 \\
Parlama noktas $\left({ }^{\circ} \mathrm{C}\right)$ & $>55$ & $>100$ \\
Alt ısıl değeri $(\mathrm{kJ} / \mathrm{kg})$ & 42640 & 39576 \\
\hline
\end{tabular}

\section{B. EGR UYGULAMASI}

Deneysel çalışmalarda motora $\% 10, \% 15$ ve $\% 20$ oranlarında EGR uygulanmıştır. EGR'li deney adımları öncelikle EGR'siz olarak yapılmıştır ve tüketilen $\mathrm{CO}_{2}$ miktarları ölçülmüştür. Ölçülen $\mathrm{CO}_{2}$ miktarlarına göre EGR oranları hesaplanmıştır. Emme hattına gönderilen egzoz gazı miktarının hesaplanmasında denklem 1 kullanılmıştır.

$\operatorname{EGR}(\%)=\frac{\left[\left(\mathrm{CO}_{2}\right)_{\text {emme manifoldu }}-\left(\mathrm{CO}_{2}\right)_{\text {çevre }}\right]}{\left[\left(\mathrm{CO}_{2}\right)_{\text {egzoz manifoldu }}\right]} \times 100$

Motorda yanma sonucu oluşan egzoz gazlarının bir kısmının emme manifolduna geri gönderilmesi için boru bağlantısı yapılmıştır. Bu hat üzerine, egzoz manifoldundan çıkan egzoz gazlarının soğutulmasını sağlayan EGR soğutucusu ve EGR oranının ayarlanmasını sağlayan çok turlu vana konumlandırılmıştır.

\section{DENEY DÜZENEĞİ}

Deneyler esnasında kullanılan motorun teknik özellikleri Tablo 2'de verilmiştir. Deney Düzeneği ise Şekil 1'de gösterilmektedir. 
Tablo 2. Deney motorunun teknik özellikleri

\begin{tabular}{cc}
\hline Motor Tipi & Süper Star \\
\hline Piston Çap1 [mm] & 108 \\
Strok [mm] & 100 \\
Silindir Sayis1 & 1 \\
Strok Hacmi [dm $\left.{ }^{3}\right]$ & 0,92 \\
Güç, 2200 d/d, [kW] & 12 \\
Enjektör Açma Basinc1 [bar] & 225 \\
Püskürtme Avans1 [Krank Aç1s1] & 29 \\
Sikıştırma Oranı & 17 \\
Maksimum Devir [d/d] & 2500 \\
Soğutma Tipi & Su \\
Püskürtme Tipi & Direkt Enjeksiyon \\
Piston Tipi & Çanak Piston \\
\hline
\end{tabular}

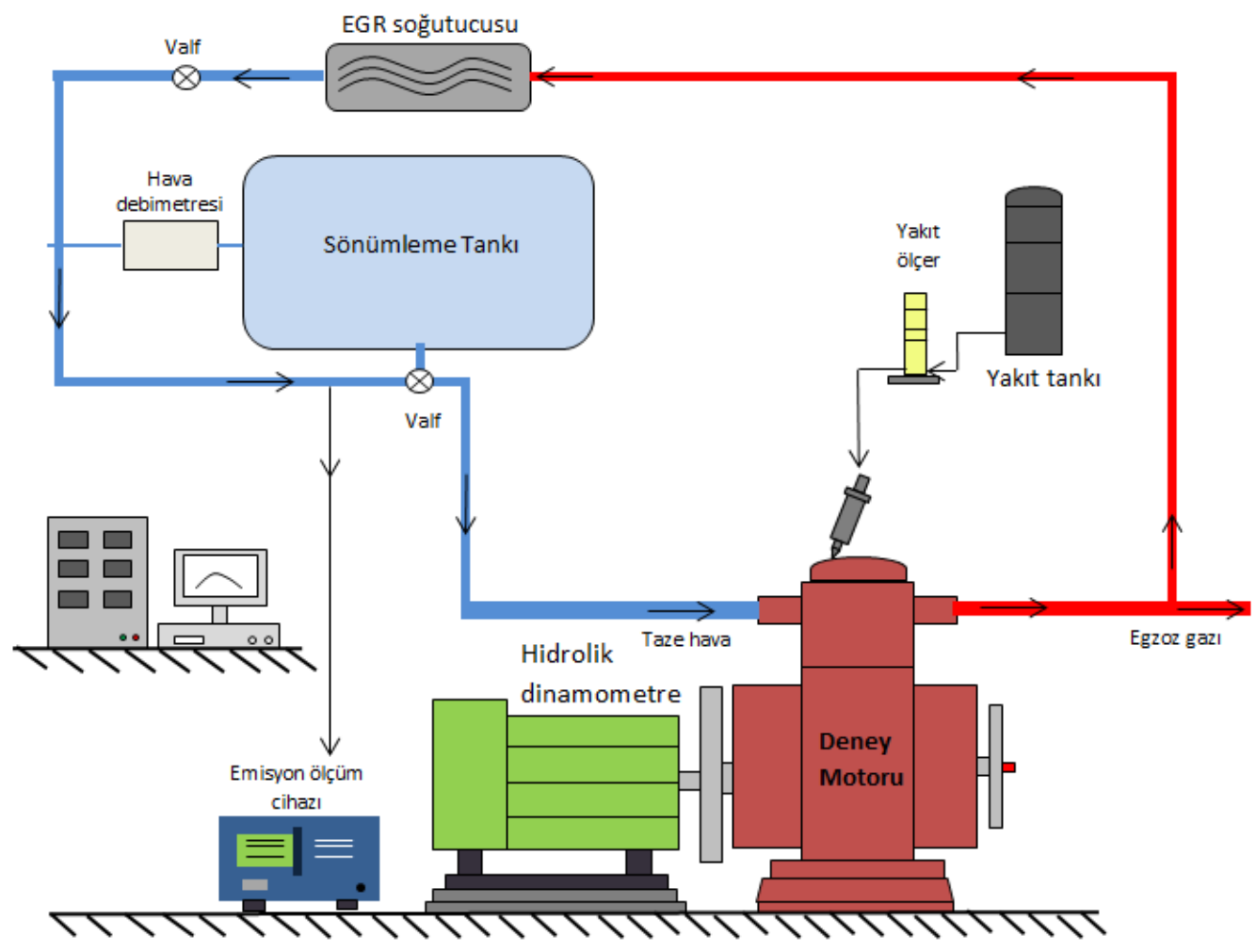

Şekil 1. Deney düzeneği

Deneysel çalışmalarda motor $50 \mathrm{~kg}$ yük tutma kapasiteli hidrolik bir dinamometre ile yüklenmiştir. Dinamometrenin koluna motorun ürettiği gücü tespit etmek için $0,1 \mathrm{~kg}$ hassasiyetle çalışan $\mathrm{S}$ tipi yük hücresi (Loadcell) bağlanmıştır. Ortam sıcaklığı, egzoz gaz sıcaklığı ve soğutma suyu giriş ve çıkış sıcaklıkları NiCr-Ni tipi Elimko 680 marka sıcaklık ölçüm sensörleri kullanılarak ölçülmüştür. Uygun püskürtme avansının tespit edilmesi için standart motorda testler yapılmış ve püskürtme avansı $29^{\circ}$ olarak belirlenmiştir. Deney motorunun maksimum momenti 1600 d/d'da 44,5 Nm olarak ölçülmüştür. Deney motorundan veriler alınmadan önce motorun kararlı hale gelmesi sağlanmıştır. Deneyler boyunca soğutma suyu çıkış sıcaklığı $80^{\circ} \mathrm{C}$ 'de sabit tutulmuştur. NO emisyonlarının ölçümü için Bosh BAE 060 marka emisyon cihazı kullanılmıştır. Yakıt sarfiyatının ölçümü hacimsel debi ölçüm kabı ile yapılmıştır. Deneyler tam yükte ve 1600 d/d, 2400 d/d motor hızlarında gerçekleştirilmiştir. Tablo 3 'te ölçülen parametreler ve ölçüm cihazlarının özellikleri verilmiştir. 
Tablo 3. Ölçülen parametreler ve ölçüm cihazlarının özellikleri

\begin{tabular}{ccccc}
\hline Ölçülen paremetreler & Birim & $\begin{array}{c}\text { Ölçüm } \\
\text { aralığı }\end{array}$ & Ölçme aleti & $\begin{array}{c}\text { Ölçüm } \\
\text { hassasiyeti }\end{array}$ \\
\hline Motor Devri & dev/dak & $0-9999$ & $\begin{array}{c}\text { Dijital } \\
\text { takometre }\end{array}$ & 1 dev/dak \\
Egzoz sıcaklığı & ${ }^{\circ} \mathrm{C}$ & $0-1000$ & Ni-Cr-Ni & $1{ }^{\circ} \mathrm{C}$ \\
Fren terazi kuvveti & $\mathrm{Kg}$ & $0-100$ & $\mathrm{Su}$ freni & $0,1 \mathrm{Kg}$ \\
Azot oksit (NO), ppm & $\mathrm{ppm}$ & $0-2000$ & Bosh BAE 060 & $\pm 5 \mathrm{ppm}$ \\
\hline
\end{tabular}

\section{DENEY TASARIMI}

Deney tasarımı Taguchi yöntemi ile Minitab programında yapılmıştır. Bu çalışmada, iki farklı devirde farklı oranlarda biyodizel ve EGR kullanımının motor performans ve NO emisyonlarına etkileri tespit edilmek istendiği için bu parametreler üzerindeki diğer etkili faktörler optimum düzeyde tutulmuştur. Çalışmada seçilen kontrol edilebilen faktör ve seviyeleri Tablo 4'te verilmiştir. Daha önce yapılan deneysel denemeler ve literatürdeki çalışmalardan faydalanılarak biyodizel ve EGR'nin 4 seviyesi; motor devrinin ise 2 seviyesi seçilmiştir.

Tablo 4. Faktör ve seviyeleri

\begin{tabular}{|c|c|c|c|c|c|}
\hline Sembol & Faktör & Seviye 1 & Seviye 2 & Seviye 3 & Seviye 4 \\
\hline $\mathbf{A}$ & $\begin{array}{c}\text { Biyodizel, } \\
\text { m \% }\end{array}$ & B0 & B10 & B20 & B50 \\
\hline B & EGR, \% & EGR0 & EGR10 & EGR15 & EGR20 \\
\hline $\mathrm{C}$ & Devir, $\mathrm{d} / \mathrm{d}$ & 1600 & 2400 & & \\
\hline
\end{tabular}

Tam faktöriyel deney planlarında çok sayıda deney yapılması, zaman ve maliyet açısından olumsuz sonuçlar doğurmaktadır. Taguchi deney tasarım yönteminde ortogonal deney planları sayesinde çok sayıda faktör ile az sayıda deney yapılarak optimum sonuçlara ulaşılmaktadır. Ortogonal dizi, deneme sırasında bir faktörün seviyelerinin diğer faktörlerin seviyeleri ile eşleştirilmesidir [32]. Bu çalışmada, 2 faktör 4 seviyeli, 1 faktör 2 seviyeli seçilerek bu bilgiler Minitab programına girilmiş ve bu faktör ve

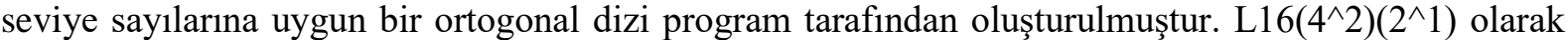
ifade edilen ortogonal dizi Tablo 5'te verilmiştir. Bu tabloya göre 16 deney 3 tekrarlı olarak, rassal sıra ile gerçekleştirilmiştir.

Motor deneylerinden elde edilen veriler sonucu motor momenti, efektif güç, ÖYS ve efektif verim değerleri hesaplanmıştır. NO emisyonlarının egzozdaki miktarı ppm olarak ölçülmüştür. Hesaplamalarda kullanılan formüller Tablo 6'da verilmektedir.

Tablo 5. L16 ortogonal dizisi

\begin{tabular}{cccc}
\hline $\begin{array}{c}\text { Deney } \\
\text { No }\end{array}$ & Biyodizel & EGR & Devir \\
\hline 1 & B0 & EGR0 & 1600 \\
2 & B0 & EGR10 & 1600 \\
3 & B0 & EGR15 & 2400 \\
4 & B0 & EGR20 & 2400 \\
5 & B10 & EGR0 & 1600 \\
6 & B10 & EGR10 & 1600
\end{tabular}


Tablo 5 (devam). L16 ortogonal dizisi

\begin{tabular}{cccc}
7 & B10 & EGR15 & 2400 \\
8 & B10 & EGR20 & 2400 \\
9 & B20 & EGR0 & 2400 \\
10 & B20 & EGR10 & 2400 \\
11 & B20 & EGR15 & 1600 \\
12 & B20 & EGR20 & 1600 \\
13 & B50 & EGR0 & 2400 \\
14 & B50 & EGR10 & 2400 \\
15 & B50 & EGR15 & 1600 \\
16 & B50 & EGR20 & 1600 \\
\hline
\end{tabular}

Tablo 6. Hesaplamalarda kullanılan formüller

\begin{tabular}{cccc}
\hline $\begin{array}{c}\text { Moment } \\
(\mathrm{Nm})\end{array}$ & $\begin{array}{c}\text { Efektif Güç } \\
(\mathrm{kW})\end{array}$ & $\begin{array}{c}\text { ÖYS } \\
(\mathrm{g} / \mathrm{kWh})\end{array}$ & Efektif verim \\
\hline$M_{d}=F \cdot L$ & $P_{e}=\frac{2 \pi \cdot F \cdot L \cdot n}{1000}$ & $b_{e}=\frac{3600 \cdot \Delta V \cdot \rho_{y}}{P_{e} \cdot \Delta t}=\frac{3600 \cdot \dot{m}_{y}}{P_{e}}$ & $\eta_{e}=\frac{P_{e}}{\dot{m}_{y} \cdot H u}$
\end{tabular}

Tüm parametrelerin değerleri bulunduktan sonra Minitab üzerinde analizler yapılmıştır. Taguchi deney tasarım yöntemini geleneksel deney tasarım yöntemlerinden ayıran en önemli özellik performans kriterini belirleyen S/N oranı adında bir kriterin kullanılmasıdır [33]. Buna göre öncelikle moment, efektif güç, ÖYS, efektif verim ve $\mathrm{NO}$ emisyonları değerlerinin uygun $\mathrm{S} / \mathrm{N}$ oranı formülleri belirlenmiştir. Motor momenti, efektif güç ve efektif verimin istenilen değerleri en yüksek değerleri olduğu için Taguchi'nin önerdiği ‘en büyük en iyi' (Larger is better) formülü kullanılmıştır. ÖYS ve NO emisyonları için istenilen değerler en düşük değerler olduğu için 'en küçük en iyi' (Smaller is better) formülü kullanılmıştır. Seçilen S/N oranlarının formülleri denklem 2 ve 3 ile gösterilmektedir.

En büyük en iyi;

$\mathrm{S} / \mathrm{N}=-10 \log \left[\frac{1}{n} \sum_{i=1}^{n} \frac{1}{y_{i}^{2}}\right]$

En küçük en iyi;

$\mathrm{S} / \mathrm{N}=-10 \log \left[\frac{1}{n} \sum_{i=1}^{n} y_{i}^{2}\right]$

$\mathrm{S} / \mathrm{N}$ oranlarına göre her bir performans parametresi ve emisyon değeri için Minitab programında analizler yapılmıştır. Elde edilen analiz sonuçlarına göre optimum kombinasyonlar belirlenmiştir. Daha sonra faktörlerin motor performans parametreleri üzerindeki etki yüzdelerini tespit etmek için ANOVA analizi yapılmıştır. ANOVA analizi hesaplamalarında kullanılan formüller denklem 4, 5, 6, 7 ve 8 ile gösterilmiştir.

$\mathrm{SS}_{\mathrm{T}}=\left[\sum_{\mathrm{i}=1}^{\mathrm{N}}(\mathrm{S} / \mathrm{N}) \mathrm{i}^{2}\right]-\frac{\mathrm{T}^{2}}{\mathrm{~N}}$ 
$\mathrm{SS}_{\mathrm{A}}=\left[\sum_{\mathrm{i}=1}^{\mathrm{K}_{\mathrm{A}}}\left(\frac{\mathrm{A}_{\mathrm{i}}^{2}}{\mathrm{n}_{\mathrm{Ai}}}\right)\right]-\frac{\mathrm{T}^{2}}{\mathrm{~N}}$

$\mathrm{v}_{\text {total }}=\mathrm{N}-1$

$\mathrm{V}_{\text {factor }}=\frac{\mathrm{SS}_{\text {faktör }}}{\vartheta_{\text {faktör }}}$

$F_{\text {factor }}=\frac{V_{\text {faktör }}}{V_{\text {hata }}}$

$\mathrm{SS}_{\mathrm{T}}$ toplam değişkenliğe sahip olan karelerin toplamını, $\mathrm{N}$ toplam deney sayısını, $\mathrm{SS}_{\mathrm{A}} \mathrm{A}$ faktörüne bağlı karelerin toplamını, $K_{A}$ ise $A$ faktörü için seviye sayısını belirtir. $A_{i}$, A faktörünün toplam seviyesinin toplamını, $\mathrm{n}_{\mathrm{Ai}}$ ise $\mathrm{A}$ faktörünün seviyesinin toplamıdır. $\mathrm{T}$, deneylerin toplam $\mathrm{S} / \mathrm{N}$ oranının toplamın1, $\mathrm{V}$ ise serbestlik derecelerini ifade eder. $\mathrm{V}_{\text {faktör, faktörün varyansını, }} \mathrm{SS}_{\text {faktör, faktörün }}$

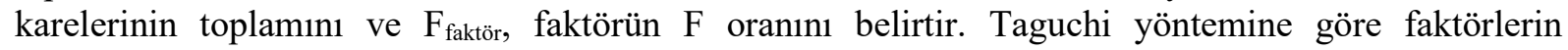
seviyeleri $\% 90$ ile $\% 99$ güven aralı̆̆ında anlamlıdır.

\section{ARASTIRMA BULGULARI}

Motor tam yükte çalışırken 1600 ve 2400 d/d'da, farklı biyodizel ve EGR oranları ile yapılan deneysel çalışmada motor performans parametrelerindeki ve NO emisyonundaki değişimler Taguchi istatistiksel deney tasarım yöntemi kullanılarak incelenmiştir.

\section{A. S/N ORANI ANALIZLERI}

Şekil 2'de motor döndürme momentine etki eden faktör ve seviyelerinin değişimleri görülmektedir. Momenti maksimum yapan değer B20 biyodizel karışımında, EGR uygulanmadığında (EGR0) ve 1600 d/d'da elde edilmiştir. En iyi kombinasyon A3-B1-C1'dir.

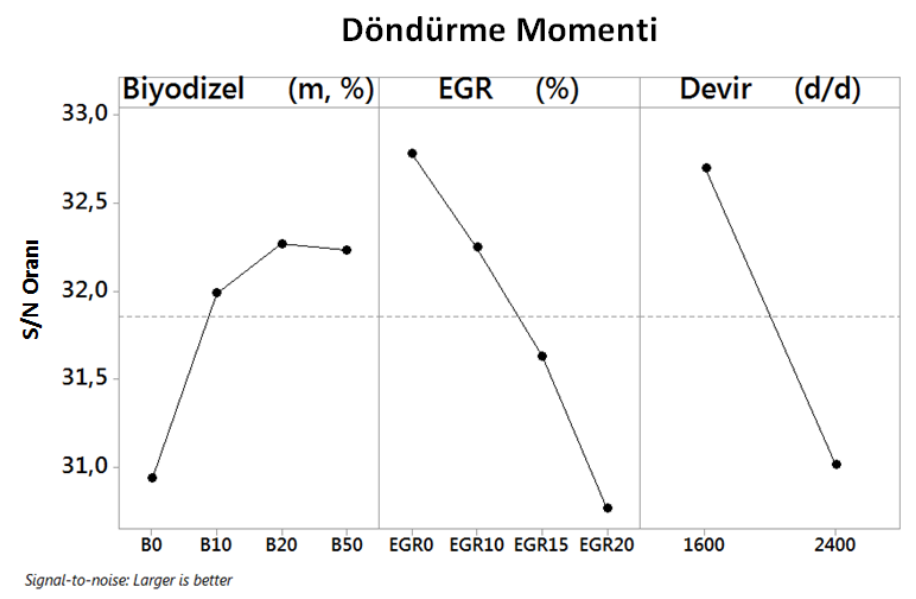

Şekil 2. Moment için faktör seviyeleri S/N oranlart

Şekil 3'te motor efektif gücüne etki eden faktör ve seviyelerinin değişimleri görülmektedir. Efektif gücün optimum değeri B20 biyodizel karışımında, EGR uygulanmadığında (EGR0) ve $2400 \mathrm{~d} / \mathrm{d}$ 'da elde edilmiştir. En iyi kombinasyon A3-B1-C2'dir. 
Şekil 2 ve 3'te faktör ve seviyelerinin tam yükte döndürme momenti ve efektif güce etkisi görülmektedir. B0, B10, B20 ve B50 yakıtlarıyla yapılan testlerde momentin ve efektif gücün değişimleri incelendiğinde en iyi moment ve efektif güç değerlerinin B20 yakıtında elde edildiği görülmektedir. B10 yakıtında standart motora göre kayda değer bir iyileşme kaydedilmiştir. B50 yakıtında ise B20 yakıtına göre kötüleşme meydana gelmiştir. Biyodizel karışım yakıtları kullanıldığında standart motora göre moment ve efektif güçte meydana gelen iyileşmelerin sebebinin dizel yakıta göre biyodizelin oksijence zengin içeriğe sahip olmasından ileri geldiği düşünülmektedir. Yakıt içerisindeki oksijen miktarı arttıkça yanma verimi iyileşmekte ve motor döndürme momenti artmaktadır. B10 ve B20 yakıtının kullanılmasıyla motor performansının iyileşmesinin bir diğer sebebi ise setan sayısının yükselmesi olduğu tahmin edilmektedir. Saf dizel yakıtı, B10 ve B20 dikkate alındığında; biyodizel oranı arttığında motor performansı iyileşmektedir. Fakat "saf dizel yakıtı ile B10 kullanımını" kıyaslandığında motor performasındaki artış "B10 ile B20 kullanımı" kıyaslandığındaki motor performansındaki artışa göre daha fazladır. Bir diğer anlatımla, biyodizel oranı arttıkça motor performansındaki artış azalmaktadır. Bu durumun viskozitenin artışına ve 1sıl değerin azalmasına bağlı olduğu tahmin edilmektedir. Yani, saf dizel yakıtından B20'ye doğru gidilirken motor performansındaki artı̧̧ azalmaktadır. B50 yakıtının kullanılmasıyla B20 yakıtına göre momentin azalmasının biyodizelin dizel yakıta göre düşük alt 1sıl değere sahip olması ile ilgili olduğu düşünülmektedir. Dolayısıyla B50 yakıt karışımının alt 1sıl değeri dizel yakıta oranla az olmakta ve yakıtın yanması sonucunda elde edilen enerji miktarı azalmaktadır. Bu durum da moment ve efektif gücün azalmasına sebebiyet vermektedir. B50 yakıtında momentin azalmasının diğer bir sebebi, biyodizel yakıtlarının dizel yakıta göre daha yüksek viskoziteye ve yoğunluğa sahip olmasıdır. Özellikle yüksek devirlerde sürtünmeler sebebiyle yakıtın pompayı doldurma gecikmesi dizel yakıta oranla biyodizelde yüksektir [34]. Literatürde moment ve efektif güç açısından en iyi sonuçların alındığı biyodizel oranının $\% 10$ ve $\% 20$ arasında olduğu görülmektedir $[1,8-10,18]$.

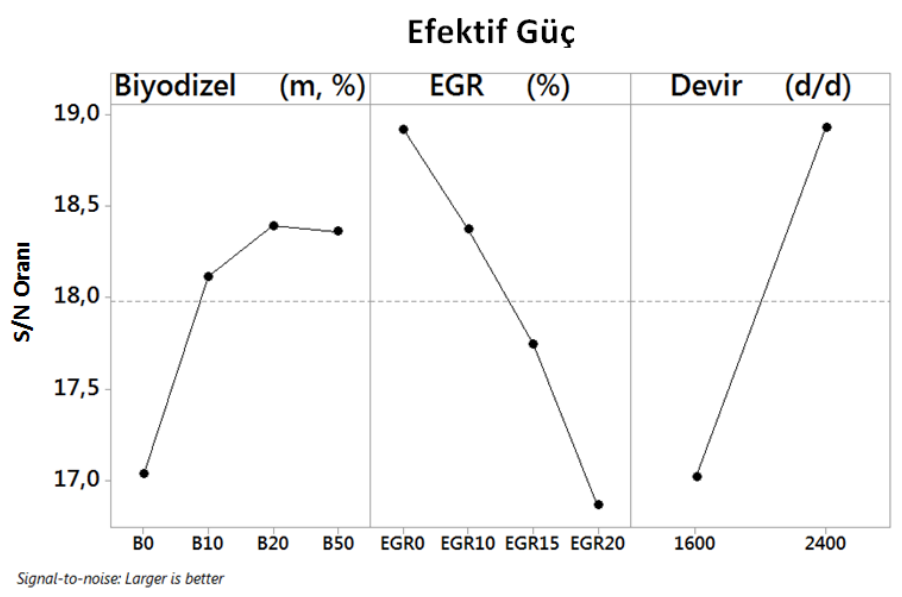

Şekil 3. Efektif güç için faktör seviyeleri $S / N$ oranları

Motora EGR uygulanması nedeniyle dolgu içerisindeki oksijen miktarının ve yanma hızının azalması motor performansını kötüleştirmektedir. S/N analizi sonuçlarına bakıldığında EGR'nin tüm oranlarında moment ve efektif gücün azaldığı görülmektedir.

Genel olarak atmosferik motorlarda momentin en yüksek olduğu devir karakteristik eğrilerden bilindiği üzere orta bir devirdir. Deney motorunda en yüksek moment $1600 \mathrm{~d} / \mathrm{d}$ 'da elde edilmiştir. Bu devirden sonra devir arttıkça moment azalır. Bunun nedeni silindire girecek karışım miktarının azalması ve artan sürtünme kayıplarıdır. Diğer yandan efektif güç moment arttıkça artar, ancak efektif güç momente bağlı olduğu gibi motor devrine de bağlıdır. Devir arttıkça çevrim sayısındaki artmaya bağlı olarak efektif güç artmaktadır. Bu durumda grafiğe göre en yüksek efektif güç değeri 2400 $\mathrm{d} / \mathrm{d}$ 'da elde edilmiştir. 
Şekil 4'te ÖYS'ye etki eden faktör ve seviyelerinin değişimleri görülmektedir. ÖYS'nin optimum değeri B20 biyodizel karışımında, EGR uygulanmadığında (EGR0) ve 1600 d/d'da elde edilmiştir. En iyi kombinasyon A3-B1-C1'dir.

ÖYS'nin tam yükte faktör ve seviyelerine göre değişimi Şekil 4'te görülmektedir. Dizel yakıtına biyodizel ilave edildiğinde ve biyodizel oranı arttıkça (B20'ye kadar) ÖYS azalma göstermiştir. En düşük ÖYS B20 yakıtında elde edilmiştir. \%20 biyodizel içeren yakıtta ÖYS'nin standart motora göre düşük olması, biyodizelin oksijen içeriğinden dolayı yanma kalitesinin artması ile açıklanabilir. Aynı zamanda biyodizel kullanıldığında ÖYS'nin azalmasının bir diğer sebebi olarak gücün artması gösterilebilir. \%20 biyodizel oranından sonra, biyodizelin karışım içerisindeki yüzdesi ile orantılı olarak ÖYS dizel yakıta göre artmaktadır. B50 yakıtındaki bu artışın, biyodizelin enerji içeriğinin dizel yakıta oranla düşük olmasından ileri geldiği düşünülmektedir. Biyodizelin oksijen içeriği fazla olsa da alt 1sıl değerinin düşük olması, özellikle biyodizelin yüksek oranlarında yanma verimini artırmada yeterli olmadığ 1 tahmin edilmektedir. Ayrıca Özsezen vd. [35] dizele göre biyodizel yoğunluğunun fazla olmasının, püskürtülen yakıt miktarının fazla çıkmasına neden olduğunu ifade etmektedirler. Bunun sebebinin hacimsel olarak aynı miktarda yakıt püskürtülmesine rağmen kütlesel olarak ele alındığında daha fazla yakıt verildiği ile ilgili olduğunu belirtmektedirler.

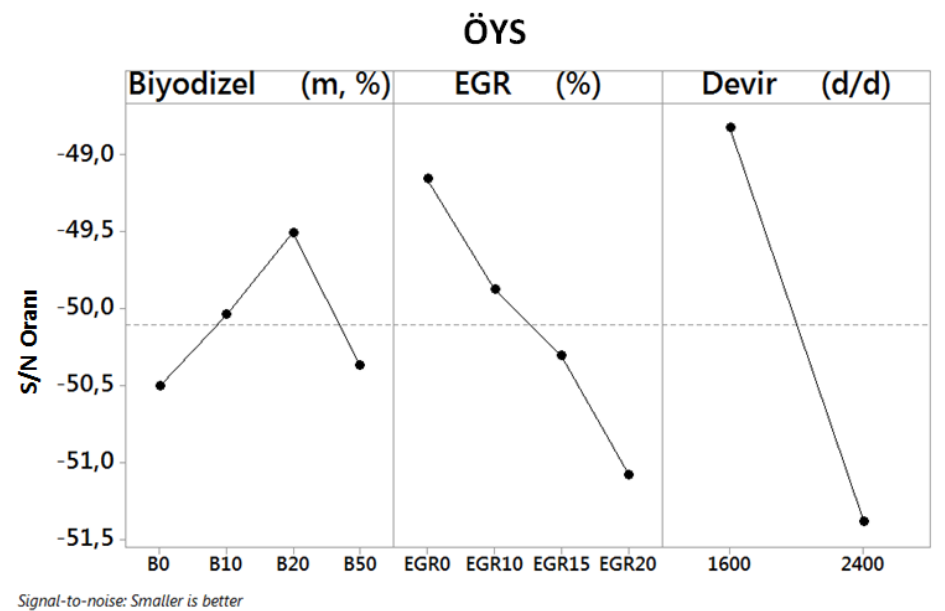

Şekil 4. ÖYS için faktör seviyeleri S/N oranlart

Motora EGR uygulandığında ve EGR oranı arttıkça ÖYS'nin kötüleştiği görülmektedir. Artan EGR oranı karışımın fakirleşmesine ve yanmanın kötüleşmesine yol açmaktadır. Ayrıca EGR uygulaması ile yanma sonu oluşan ısının bir bölümü egzoz gazları tarafından soğurulduğundan açığa çıkan maksimum 1sı miktarı azalmakta, ve bu durumda ÖYS artmaktadır.

1600 d/d'da 2400 d/d'ya göre ÖYS daha azdır. Devir arttıkça aynı hacimdeki yakıtın tüketim süresinin azalmasına ve dolayısıyla daha fazla yakıtın tüketilmesine bağlı olarak ÖYS artmaktadır.

Şekil 5 'te motor efektif verimine etki eden faktör ve seviyelerinin değişimleri görülmektedir. Efektif verimin optimum değeri B20 biyodizel karışımında, EGR uygulanmadığında (EGR0) ve 1600 d/d'da elde edilmiştir. En iyi kombinasyon A3-B1-C1'dir. 


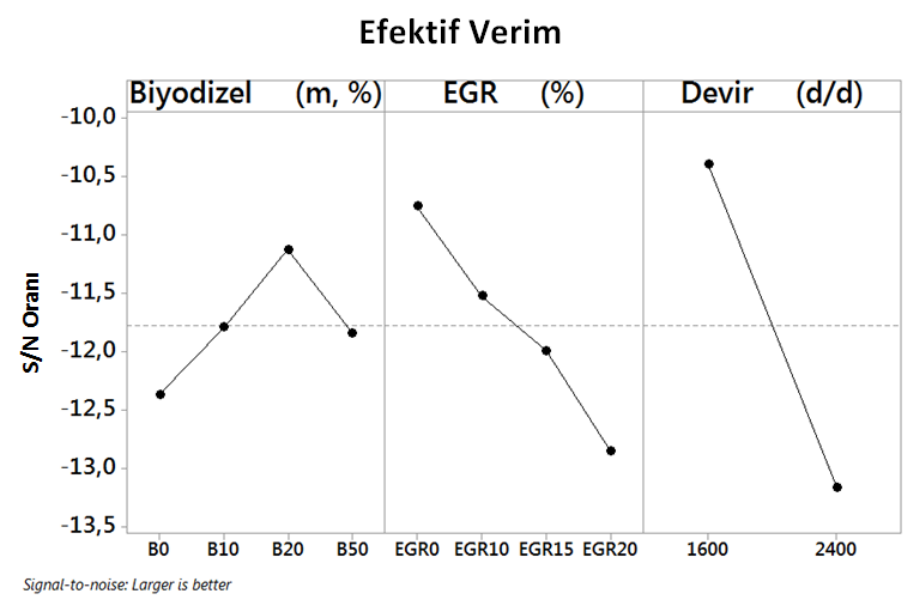

Şekil 5. Efektif verim için faktör seviyeleri S/N oranlar

Şekil 5'te motor tam yükte çalışırken faktör ve seviyelerinin efektif verime etkisi görülmektedir. Dizel yakıta göre B10 yakıtında efektif verimin bir miktar iyileştiği, B20 yakıtında en iyi seviyeye ulaştığı, bundan sonra yakıt içerisindeki biyodizel oranı arttıç̧a (B10 ve B20'ye göre) verimin bir miktar kötüleştiği görülmektedir. Dolayısıyla B20 biyodizel karışım yakıtında optimum verim elde edilmiştir. Biyodizelin bünyesinde yaklaşık \%11 oranında oksijen bulunması yanmayı iyileştirici bir etki yapmaktadır. Ancak biyodizelin dizel yakıta göre daha düşük alt 1sıl değere sahip olması, yakıt içerisindeki biyodizel oranı arttıkça (B20-B50 arası) yakıt karışımının da alt 1sıl değerinin düşmesine sebep olmaktadır. Karışımın alt ısıl değeri düştükçe sisteme enerji girişi az olmakta, dolayısıyla verim düşmektedir.

EGR'nin deney sisteminde devreye girmesiyle efektif verimin kötüleştiği görülmektedir. EGR ile silindire tekrar alınan egzoz gazları ortamın oksijen konsantrasyonunu düşürdüğünden yanma kalitesi azalmaktadır. Bu durumda elde edilen verim de düşmektedir.

Devir ile efektif verimin değişimine bakıldığında motor yüksek devirlerde çalıştığında motordan alınan efektif verimin azaldığ 1 ifade edilebilir. Dolayısıyla $1600 \mathrm{~d} / \mathrm{d}$ 'da daha yüksek bir verim elde edilmiştir.

Şekil 6' da NO emisyonlarına etki eden faktör ve seviyelerinin değişimleri görülmektedir. NO emisyonunun optimum değeri dizel yakıtında (B0), \%20 EGR oranında (EGR20) ve $2400 \mathrm{~d} / \mathrm{d}$ 'da elde edilmiştir. En iyi kombinasyon A1-B4-C2'dir.

\section{NO Emisyonu}

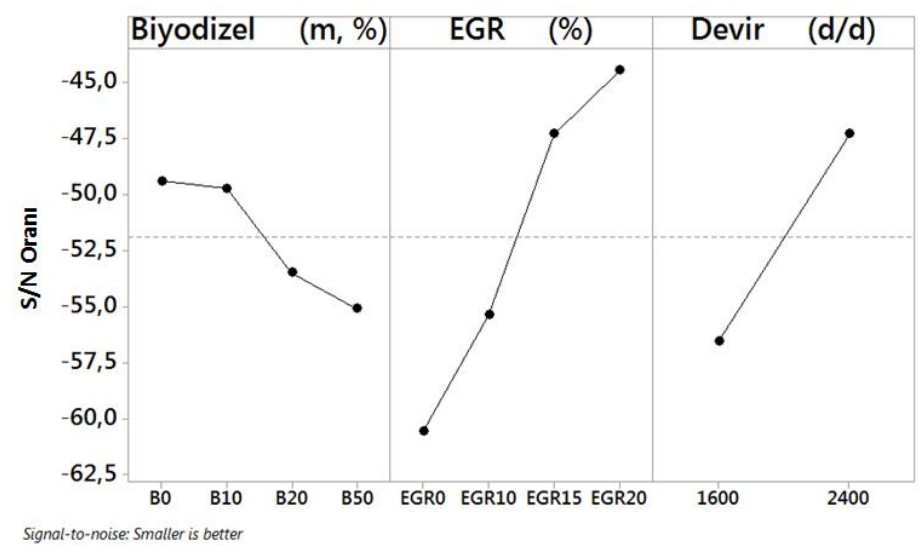

Şekil 6. NO emisyonu için faktör seviyeleri $S / N$ oranlar 
Şekil 6' da görüldüğü gibi motor tam yükteyken en düşük NO emisyonu dizel yakıt kullanımında tespit edilmiştir. NO emisyonu karışımdaki biyodizel yüzdesinin artmasıyla artı̧̧ göstermiştir. Bu durumun, biyodizelin bünyesindeki oksijenin, yakıt demetinin çevresindeki bölgesel oksijen yoğunluğunu artırması sonucu yanma odasındaki bölgesel 1sı çıkış hızı ve sıcaklığının artmasıyla ilgili olduğu düşünülmektedir. NO’lar, yüksek sıcaklıkta ve önemli miktardaki hava ile yanma değişim alanlarında üretilir. Bu alanlardaki NO oluşumu, yanma işleminin ilk aşamasındaki serbest oksijene ve maksimum sıcaklığa bağlıdır. En fazla NO emisyonu miktarı, yanma veriminin en yüksek olduğu yüksek hava fazlalık katsayısına sahip egzoz gazında görülür. Dizel motorları yüksek hava fazlalık katsayısı ile çalıştıkları için NO emisyonları bu motorlarda daha fazla görülür [36].

Egzoz gazları silindir içine geri verildiğinde yanma odasındaki asal gaz yoğunluğu büyük oranda artmaktadır ve buna bağlı olarak alev sıcaklığında azalma meydana gelir. Ayrıca taze dolgudaki oksijen yoğunluğu azalır ve azot oksidin oksijen ile reaksiyona girebilmesi için ortamda yeterli oksijen bulunmadığından NO oluşumu azalır [14].

Yüksek devirlerde yanmanın kötüleşmesi ve avansın yeterli gelmemesi sonucu NO emisyonlarının oluşumunun azaldığı bilinmektedir. Bu çalışmada, motor deneyleri iki farklı devir hızında gerçekleştirilmiştir. Dolayısıyla $1600 \mathrm{~d} / \mathrm{d}$ ve $2400 \mathrm{~d} / \mathrm{d}$ ile yapılan deney sonuçları karşılaş̧ırılacak olursa Şekil 6' da belirtildiği gibi yüksek devirde (2400 d/d) daha düşük NO emisyonu tespit edilmiştir. Devir sayısı arttıkça NO miktarının azalmasının, NO oluşumu için yeterli sürenin kalmamasından kaynaklandığı düşünülmektedir.

\section{B. ANOVA ANALIZIi}

Tablo 7 incelendiğinde ANOVA analizi sonuçlarına göre faktörlerin moment, efektif güç, efektif verim, ÖYS ve NO emisyonları üzerindeki etkileri görülmektedir.

Biyodizel, moment ve efektif güç üzerinde \%99 güven aralığında etkilidir. EGR ve motor devri ise moment ve efektif güç üzerinde \%99.99 güven aralığında etkilidir. Bu durumda EGR ve motor devrinin moment ve efektif güç üzerinde biyodizele göre daha etkili oldukları söylenebilir.

Motor devri, efektif verim ve ÖYS üzerinde \%99.99 güven aralığında, devir efektif verim ve ÖYS üzerinde $\% 99$ güven aralığında etkilidir. Biyodizel ise bu faktörler üzerinde daha az etkilidir.

Biyodizel, NO emisyonları üzerinde \%99 güven aralığında etkilidir. EGR ve motor devri ise NO emisyonları üzerinde \%99.99 güven aralığında etkilidir. EGR ve motor devrinin NO emisyonu üzerinde biyodizele göre daha etkili oldukları ifade edilebilir.

Genel optimizasyonu belirlemek için $\mathrm{S} / \mathrm{N}$ oranları tablosu oluşturulurken 0,05 'ten düşük $\mathrm{P}$ değerine sahip faktörlerin $\mathrm{S} / \mathrm{N}$ oranları tabloda verilmektedir. Diğer $\mathrm{S} / \mathrm{N}$ oranlarının, anlamlı bulunmadıkları için tabloya aktarılmalarına gerek yoktur [27]. Öncelikle, Tablo 8'de herhangi bir faktör için en yüksek $\mathrm{S} / \mathrm{N}$ oranı belirlenir. İkinci olarak, en büyük $\mathrm{S} / \mathrm{N}$ oranına karş1lık gelen faktör seviyesi belirlenir ve böylece genel optimizasyon elde edilir. A faktörü için en yüksek S/N oranı 32,27'dir ve seviye 3'te meydana gelir. B faktörü için en yüksek $\mathrm{S} / \mathrm{N}$ oranı 32,78 'dir ve seviye 1'de gerçekleşir. Aynı şekilde $\mathrm{C}$ faktörü için en yüksek $\mathrm{S} / \mathrm{N}$ oran1 32,69'dur ve seviye 1'de gerçekleşir. Bu sonuçlar göz önüne alındığında genel optimizasyon A3-B1-C1'dir.

Burada genel optimizasyon motor performans parametreleri üzerinde durularak yapılmıştır ve seçilen kombinasyon da performans parametrelerinin tümü için optimum sonucu verebilecek bir kombinasyondur. Eğer öncelikli hedef NO emisyonunun optimum seviyeye getirilmesi olsaydı, farklı bir kombinasyonun seçilmesi gerekirdi (A1-B4-C2). Ayrıca aynı anda hem motor performansının hem de NO emisyonlarının optimum bir seyiyeye getirilmesi için genel optimizasyon A2-B2-C1 olarak seçilebilir. 


\begin{tabular}{|c|c|c|c|c|c|c|}
\hline & Faktörler & $\begin{array}{c}\text { Serbestlik } \\
\text { Derecesi }\end{array}$ & $\begin{array}{l}\text { Kareler } \\
\text { Toplamı }\end{array}$ & $\begin{array}{c}\text { Kareler } \\
\text { Ortalaması }\end{array}$ & Fteori & Pdeğeri \\
\hline \multirow{5}{*}{ Moment } & A - Biyodizel & 3 & 4,691 & 1,5637 & $10,01 * *$ & 0,004 \\
\hline & $\mathrm{B}-\mathrm{EGR}$ & 3 & 8,92 & 2,9733 & $19,03 * * *$ & 0,001 \\
\hline & C - Devir & 1 & 11,232 & 11,2322 & $71,9 * * *$ & 0,000 \\
\hline & Hata & 8 & 1,25 & 0,1562 & & \\
\hline & Toplam & 15 & 26,093 & & & \\
\hline \multirow{5}{*}{$\begin{array}{l}\text { Efektif } \\
\text { Güç }\end{array}$} & A - Biyodizel & 3 & 4,902 & 1,634 & $9,95 * *$ & 0,004 \\
\hline & $\mathrm{B}-\mathrm{EGR}$ & 3 & 9,341 & 3,1137 & $18,97 * * *$ & 0,001 \\
\hline & $\mathrm{C}-$ Devir & 1 & 14,61 & 14,6097 & $89 * * *$ & 0,000 \\
\hline & Hata & 8 & 1,313 & 0,1642 & & \\
\hline & Toplam & 15 & 30,166 & & & \\
\hline \multirow{5}{*}{$\begin{array}{l}\text { Efektif } \\
\text { Verim }\end{array}$} & A - Biyodizel & 3 & 3,107 & 1,0355 & 2,91 & 0,101 \\
\hline & B - EGR & 3 & 9,257 & 3,0857 & $8,68 * *$ & 0,007 \\
\hline & C-Devir & 1 & 30,69 & 30,6898 & $86,3 * * *$ & 0,000 \\
\hline & Hata & 8 & 2,845 & 0,3556 & & \\
\hline & Toplam & 15 & 45,898 & & & \\
\hline \multirow{5}{*}{ ÖYS } & A-Biyodizel & 3 & 2,37 & 0,79 & 2,6 & 0,124 \\
\hline & B - EGR & 3 & 7,76 & 2,5865 & $8,52 * *$ & 0,007 \\
\hline & C - Devir & 1 & 26,358 & 26,3578 & $86,78 * * *$ & 0,000 \\
\hline & Hata & 8 & 2,43 & 0,3037 & & \\
\hline & Toplam & 15 & 38,917 & & & \\
\hline \multirow{5}{*}{$\begin{array}{c}\text { NO } \\
\text { Emisyonu }\end{array}$} & A - Biyodizel & 3 & 95,25 & 31,751 & $7,79 * *$ & 0,009 \\
\hline & B - EGR & 3 & 657,86 & 219,286 & $53,79 * * *$ & 0,000 \\
\hline & C-Devir & 1 & 343,09 & 343,088 & $84,15 * * *$ & 0,000 \\
\hline & Hata & 8 & 32,62 & 4,077 & & \\
\hline & Toplam & 15 & 1128,81 & & & \\
\hline
\end{tabular}

Tablo 8. S/N oranlarina göre genel optimizasyonu belirleme

\begin{tabular}{cccccccc}
\hline $\begin{array}{c}\text { Faktörler } \\
\text { /Seviyeler }\end{array}$ & $\begin{array}{c}\text { Moment } \\
\text { için S/N } \\
\text { oranı }\end{array}$ & $\begin{array}{c}\text { Efektif güç } \\
\text { için S/N } \\
\text { oranı }\end{array}$ & $\begin{array}{c}\text { ÖYS } \\
\text { için S/N } \\
\text { oranı }\end{array}$ & $\begin{array}{c}\text { Efektif } \\
\text { verim için } \\
\text { S/N oranı }\end{array}$ & $\begin{array}{c}\text { NO için } \\
\text { S/N } \\
\text { oranı }\end{array}$ & $\begin{array}{c}\text { Genel } \\
\text { Optimizasyon }\end{array}$ \\
\hline $\mathrm{A}$ & 1 & 30,94 & 17,04 & & & $-49,37$ & A3 \\
& 2 & 31,99 & 18,12 & & & $-49,72$ & \\
& 3 & 32,27 & 18,39 & & & $-53,47$ & \\
& 4 & 32,23 & 18,36 & & & $-55,09$ & B1 \\
\hline $\mathrm{B}$ & 1 & 32,78 & 18,92 & $-49,15$ & $-10,75$ & $-60,57$ & \\
& 2 & 32,25 & 18,38 & $-49,87$ & $-11,52$ & $-55,37$ & \\
& 3 & 31,63 & 17,75 & $-50,31$ & $-11,99$ & $-47,27$ & \\
& 4 & 30,77 & 16,87 & $-51,08$ & $-12,85$ & $-44,43$ & \\
\hline $\mathrm{C}$ & 1 & 32,69 & 17,02 & $-48,82$ & $-10,39$ & $-56,54$ & $\mathrm{C} 1$ \\
& 2 & 31,02 & 18,93 & $-51,39$ & $-13,16$ & $-47,28$ & \\
\hline
\end{tabular}

\section{DOĞRULAMA DENEYLERİ}

$\mathrm{S} / \mathrm{N}$ analizi ve ANOVA analizi yapıldıktan sonra doğrulama testlerinin de yapılması gerekmektedir. Bunun için önce her bir performans karakteristiği için optimum parametreler seçilir. Daha sonra bu parametrelerin kullanılmasıyla performans karakteristiğindeki gelişmeler (iyileşmeler vs.) doğrulanır [37]. Böylece, Taguchi optimizasyonu sonrasında STD motor verileri ile en iyi kombinasyon sonucu 
elde edilen veriler karşılaştırılmıştır. Bunun için öncelikle en iyi kombinasyonlara ait ortogonal dizide olmayan deney adımları yapılmış ve veriler kaydedilmiştir.

Şekil 7'de görüldüğü gibi en iyi moment, B20-EGR0-1600d/d kombinasyonunda elde edilmiştir. Bu kombinasyon ortogonal dizideki deney adımlarında mevcut değildir. Bu kombinasyona göre yapılan deneylerden elde edilen ortalama moment değeri 49,91 Nm'dir. Standart motorda (B0-EGR0-1600d/d) elde edilen moment değeri ortalaması 49,36 Nm'dir. Standart motor ile Taguchi optimizasyonu sonucu elde edilen değerler karşılaştırıldığında Taguchi optimizasyonu sayesinde \%1,11'lik bir iyileşme elde edilmiştir.

Şekil 8'e bakıldığında en iyi efektif güç, B20-EGR0-2400d/d kombinasyonunda elde edilmiştir. Bu kombinasyon ortogonal dizideki deney adımlarında vardır ve ortalama güç değeri 10,64 kW'tır. Standart motorda (B0-EGR0-2400d/d) elde edilen efektif güç değeri ortalaması 10,54 kW'tır. Standart motor ile Taguchi optimizasyonu sonucu elde edilen değerler karşılaştırıldığında Taguchi optimizasyonu ile \%0,95'lik bir iyileşme elde edilmiştir.

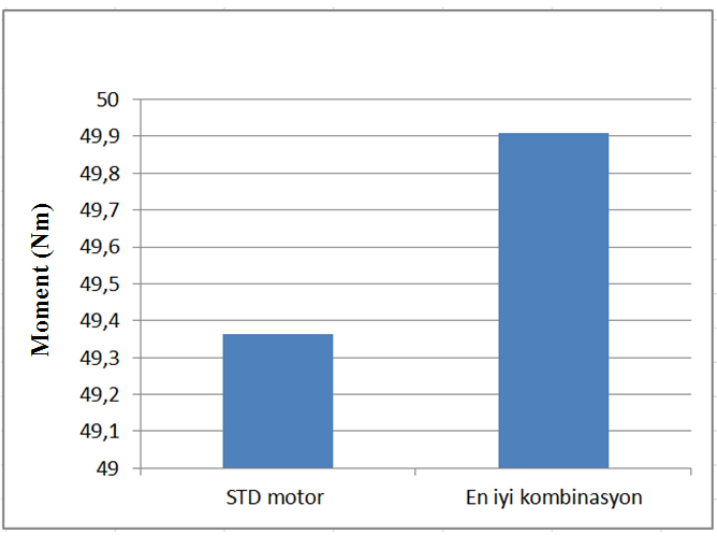

Şekil 7. Moment için karşılaştırma grafiği

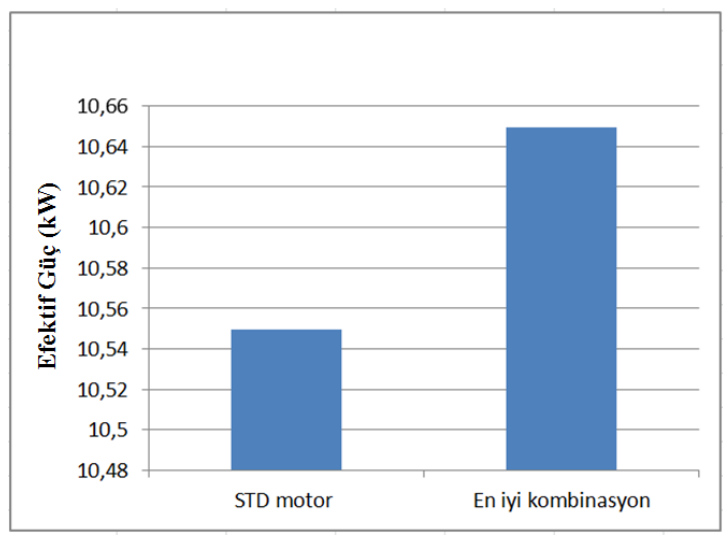

Şekil 8. Efektif güç için karşılaştırma grafiği

Şekil 9 ve 10'da görüldüğü gibi en iyi efektif verim ve ÖYS, B20-EGR0-1600d/d'da elde edilmiştir. $\mathrm{Bu}$ kombinasyon ortogonal dizideki deney adımlarında mevcut değildir. Bu kombinasyona göre yapılan deneylerde elde edilen efektif verimin ortalama değeri 0,340 , ÖYS'nin ortalama değeri ise $251,7 \mathrm{~g} / \mathrm{kWh}$ 'tir. Standart motorda (B0-EGR0-1600d/d) elde edilen efektif verim ortalamas1 0,333, ÖYS ortalamas1 253,4 g/kWh'tir. Standart motor ile Taguchi optimizasyonu sonucu elde edilen değerler karşılaştırıldığında Taguchi optimizasyonu sayesinde efektif verimde \%2,1'lik, ÖYS'de ise $\% 0,67$ 'lik bir iyileşme kaydedilmiştir.

Şekil 11'e bakıldığında en iyi NO emisyonu, B0-EGR20-2400d/d kombinasyonunda elde edilmiştir. Bu kombinasyon ortogonal dizideki deney adımlarında vardır ve ortalama NO değeri 60 ppm'dir. Standart motorda (B0-EGR0-2400d/d) elde edilen NO emisyonunun ortalama değeri 857 ppm'dir. Standart motor ile Taguchi optimizasyonu sonucu elde edilen değerler karşılaştırıldığında Taguchi optimizasyonu ile \%92,3'lük bir iyileşme elde edilmiştir. 


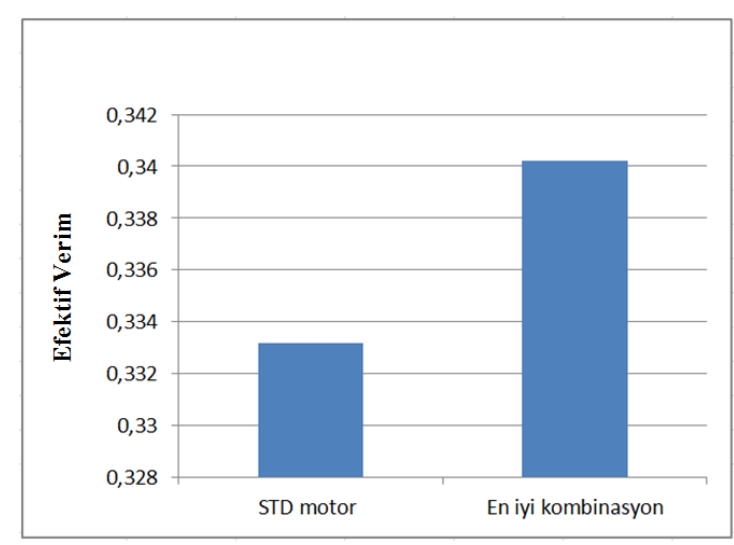

Şekil 9. Efektif verim için karşılaştırma grafiği

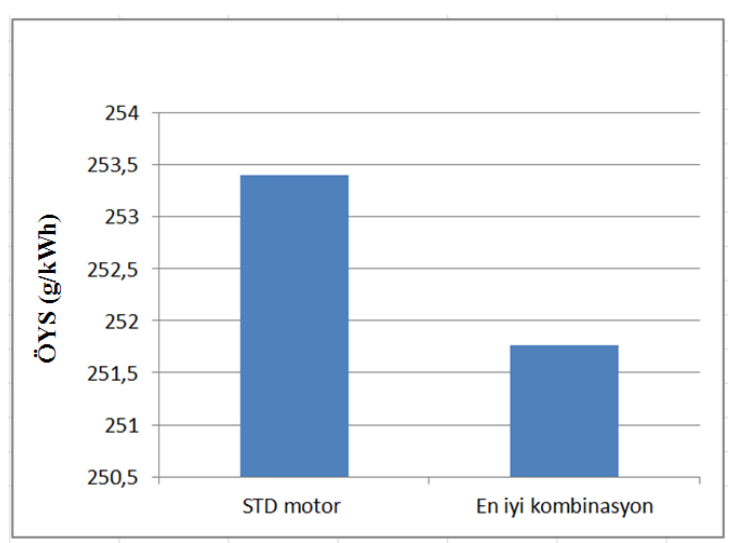

Şekil 10. ÖYS için karşılaştırma grafiği

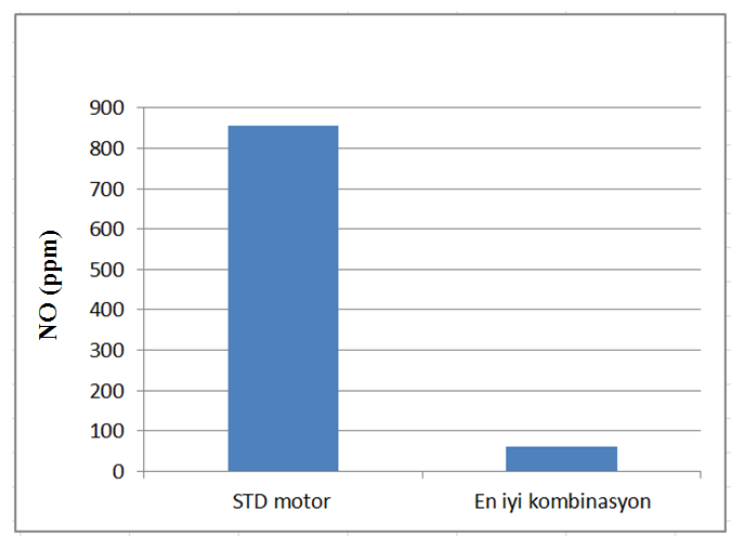

Şekil 11. NO için karşılaştırma grafiği

\section{SONUC}

Bu çalışmada, Taguchi deney tasarım yöntemi kullanılarak, tam yükte ve iki farklı devirde çalışan bir dizel motorunda farklı biyodizel ve EGR oranlarının uygulanması sonucu motor performans parametreleri ve NO emisyonundakii değişimler incelenmiştir. Yapılan deneysel incelemeler sonucunda motor devrinin, farklı biyodizel ve EGR oranlarının motor performans parametreleri ve NO emisyonları üzerinde etkili oldukları tespit edilmiştir. Genel olarak elde edilen sonuçlar aşağıdaki gibidir;

- Taguchi deney tasarım yönteminin kullanılmasının, motor performans parametrelerinin ve NO emisyonunun optimum değerlerinin bulunması açısından etkili olduğu tespit edilmiştir.

- Motor döndürme momenti açısından optimum sonuçlar B20 yakıtında, EGR uygulanmadığında (EGR0) ve $1600 \mathrm{~d} / \mathrm{d}$ 'da elde edilmiştir. Taguchi optimizasyonu sonucu momentte \% 1,11'lik bir iyileşme kaydedilmiştir.

- Efektif güç için optimum sonuçlar B20 yakıtında, EGR uygulanmadığında (EGR0) ve 2400 d/d'da, elde edilmiştir. Optimizasyon sonucu efektif güç \%0,95 oranında artış göstermiştir.

- Optimum efektif verim ve ÖYS B20 yakıtında, EGR uygulanmadığında (EGR0) ve 1600 $\mathrm{d} / \mathrm{d}$ 'da elde edilmiştir. Optimizasyon sonucu efektif verimde \%2,1'lik, ÖYS'de ise $\% 0,67$ 'lik bir iyileşme tespit edilmiştir. 
- NO emisyonlarının optimum değeri dizel yakıtında (B0), EGR20 oranında ve $2400 \mathrm{~d} / \mathrm{d}$ 'da, elde edilmiştir. NO emisyonlarının optimizasyonu sonucunda \%92,3 oranında bir iyileşme elde edilmiştir.

- ANOVA analizi sonucunda faktörlerin performans parametreleri üzerinde $\% 99$ ile $\% 99.99$ arasında etkili oldukları saptanmıştır.

- Bu çalışmada, Taguchi istatistiksel deney tasarım yöntemi kullanılarak zaman ve maliyet açısından tasarruf sağlanmıştır.

Deneysel çalışmalar neticesinde elde edilen veriler dikkate alındığında yeni çalışmalara yol göstermesi açısından bazı öneriler yapılabilir. Bu çalışmada motor performansı ve NO optimizasyonu için Taguchi yöntemi kullanılmıştır. Ancak ileriki çalışmalarda Taguchi ve YSA (Yapay Sinir Ağları) beraber kullanılarak motor performans ve emisyonlarının optimizasyon çalışmaları yapılabilir.

\section{KAYNAKLAR}

[1] H. Karabaş, "Tütün tohumu yağı metil esterinin dizel motorlarında yakıt olarak kullanılma imkanlarının araştırılması," Doktora tezi, Teknik Eğitim Fakültesi, Sakarya Üniversitesi, Sakarya, Türkiye, 2009.

[2] K.A. Abed, M.S. Gad, A.K. El Morsi, M.M. Sayed and S.A. Elyazeed, "Effect of biodiesel fuels on diesel engine emissions," Egyptian Journal of Petroleum, vol. 28, no. 2, pp. 183-188, 2019.

[3] M. Arslan ve K. Alibaş, "Laboratuvar ölçekli biyodizel üretim tesisinin projelendirilerek imal edilmesi ve bu tesiste çeşitli bitkisel yağ kaynaklarından biyodizel üretimi," Uludă̆ Üniversitesi Ziraat Fakültesi Dergisi, c. 29, s. 1, ss. 107-113, 2015.

[4] C. Haşimoğlu, "Düşük 1sı kayıplı bir dizel motorunda biyodizel kullanımının performans ve emisyon parametrelerine etkisi," Doktora tezi, Makine Mühendisliği Bölümü, Sakarya Üniversitesi, Sakarya, Türkiye, 2005.

[5] C. Haşimoğlu, Y. İçingür ve H. Öğüt, "Dizel motorlarında egzoz gazları resirkülasyonunun (EGR) motor performansı ve egzoz emisyonlarına etkisinin deneysel analizi," TÜBITTAK, s. 26, ss. 127-135, 2002.

[6] M.E. Tat, "Investigation of oxides of nitrogen emissions from biodiesel-fueled engine," Ph.D. dissertation, Iowa State University, Iowa, USA, 2003.

[7] V. Ayhan, İ. Özsert, Y. Çay, A. Çoban ve İ. Cesur, "DI bir dizel motorunda optimum buhar püskürtme oranı ve yakıt püskürtme zamanının taguchi metodu ile deneysel olarak belirlenmesi," Journal of New Results in Engineering and Natural Science, s. 8 ss. 128-136, 2018.

[8] S. Manigandan, P. Gunasekar, J. Devipriya and S. Nithya, "Emission and injection characteristics of corn biodiesel blends in diesel engine," Fuel, vol. 235, pp. 723-735, 2019.

[9] N. Usta, Ö. Can ve E. Öztürk, "Alternatif dizel motor yakıtı olarak biyodizel ve etanolün karşılaştırılması," Pamukkale Üniversitesi Mühendislik Bilimleri Dergisi, c. 11, s. 3, ss. 325-334, 2005.

[10] V. Ayhan, S. Tunca, İ. Cesur, İ. Özsert ve G. Ergen, "Ayçiçek yağı metil ester karışımlarının di bir dizel motorunun performans ve emisyonlarına etkisi," Akademik Platform Mühendislik ve Fen Bilimleri Dergisi, c. 7, s. 1, ss. 67-73, 2019. 
[11] A. Keskin ve K. Ekşi, "Dizel motorlarda mısır yağı biyodizelinin yakıt olarak kullanımının motor performans ve emisyonuna etkisi," Celal Bayar Üniversitesi Fen Bilimleri Dergisi, c. 2, s. 1, ss. 49-55, 2006.

[12] P. Rosha, S.K. Mohapatra, S.K. Mahla, H. Cho, B.S. Chauhan and A. Dhir, "Effect of compression ratio on combustion, performance, and emission characteristics of compression ignition engine fueled with palm (B20) biodiesel blend," Energy, vol. 178, pp. 676-684, 2019.

[13] L.A. Raman, B. Deepanraj, S. Rajakumar and V. Sivasubramanian, "Experimental investigation on performance, combustion and emission analysis of a direct injection diesel engine fuelled with rapeseed oil biodiesel," Fuel, vol. 246, pp. 69-74, 2019.

[14] A. Tok, "Egzoz gazı resirkülasyonunun (EGR) motor performansı üzerindeki etkisinin incelenmesi,” Yüksek Lisans tezi, Fen Bilimleri Enstitüsü, Uludağ Üniversitesi, Bursa, Türkiye, 2010.

[15] S. Verma, L.M. Das, S.C. Kaushik and S.S. Bhatti, "The effects of compression ratio and EGR on the performance and emission characteristics of diesel-biogas dual fuel engine," Applied Thermal Engineering, vol. 150, pp. 1090-1103, 2019.

[16] M.H.M. Yasin, R. Mamat, A.F. Yusop, D.M.N.D. İdris, T. Yusaf, M. Rasul and G. Najafi, "Study of a diesel engine performance with exhaust gas recirculation (EGR) system fuelled with palm biodiesel," Energy Procedia, vol. 110, pp. 26-31, 2017.

[17] T. He, Z. Chen, L. Zhu and Q. Zhang, "The influence of alcohol additives and EGR on the combustion and emission characteristics of diesel engine under high-load condition," Applied Thermal Engineering, vol. 140, pp. 363-372, 2018.

[18] V. Ayhan, Ç. Çangal, İ. Cesur, A. Çoban, G. Ergen, Y. Çay, A. Kolip and İ. Özsert, "Optimization of the factors affecting performance and emissions in a diesel engine using biodiesel and EGR with Taguchi method," Fuel, vol. 261, 2020, Art. no. 116371.

[19] P. Bhowmick, A.K. Jeevanantham, B. Ashok, K. Nanthagopal, D.A. Perumal, V. Karthickeyan, K.C. Vora and A. Jain, "Effect of fuel injection strategies and EGR on biodiesel blend in a CRDI engine," Energy, vol. 181, pp. 1094-1113, 2019.

[20] Ö. Can, E. Öztürk, H. Solmaz, F. Aksoy, C. Çınar and H.S. Yücesu, "Combined effects of soybean biodiesel fuel addition and EGR application on the combustion and exhaust emissions in a diesel engine," Applied Thermal Engineering, vol. 95, pp. 115-124, 2016.

[21] X. Shi, B. Liu, C. Zhang, J. Hu and Q. Zeng, "A study on combined effect of high EGR rate and biodiesel on combustion and emission performance of a diesel engine," Applied Thermal Engineering, vol. 125, pp. 1272-1279, 2017.

[22] M.H.M. Yasin, R. Mamat, A.F. Yusop, P. Paruka, T. Yusaf and G. Najafi, "Effects of exhaust gas recirculation (EGR) on a diesel engine fuelled with palm-biodiesel," Energy Procedia, vol. 75, pp. 30-36, 2015.

[23] Ç. Sarpkaya, "Taguchi metoduna dayalı gri ilişkiler analizi ile haşıl prosesinin optimizasyonu," Doktora tezi, Tekstil Mühendisliği Bölümü, Çukurova Üniversitesi, Adana, Türkiye, 2014.

[24] Z.Y. Wu, H.W. Wu and C.H. Hung, "Applying Taguchi method to combustion characteristics and optimal factors determination in diesel/biodiesel engines with port-njecting LPG," Fuel, vol. 117, pp. 8-14, 2014. 
[25] $\mathrm{H}$. Wu and $\mathrm{Z}$. Wu, "Using Taguchi method on combustion performance of a diesel engine with diesel/biodiesel blend and port-1nducting $\mathrm{H}_{2}$," Applied Energy, vol. 104, pp. 362-370, 2014.

[26] D.H. Lee, J.S. Park, M.R. Ryu and J.H. Park, "Development of a highly efficient lowemission diesel engine-powered co-generation system and its optimization using Taguchi method," Applied Thermal Engineering, vol. 50, pp. 491-495, 2013.

[27] M. Balk1, C. Sayın and M. Sarıkaya, "Optimization of the operating parameters based on Taguchi method in an SI engine used pure gasoline, ethanol and methanol," Fuel, vol. 180, pp. 630637, 2016.

[28] T. Ganapathy, K. Murugesan and R.P. Gakkhar, "Performance optimization of jatropha biodiesel engine model using Taguchi approach," Applied Energy, vol. 86, pp. 2476-2486, 2009.

[29] Ç. Çangal, "Farklı yakıt karışımları ve emisyon azaltma teknikleri uygulanan bir dizel motorda optimum parametrelerin Taguchi yöntemi ile belirlenmesi, Yüksek Lisans tezi, Otomotiv Mühendisliği Bölümü, Sakarya Uygulamalı Bilimler Üniversitesi, Sakarya, Türkiye, 2019.

[30] N.A. Ansari, A. Sharma and Y. Singh, "Performance and emission analysis of a diesel engine implementing polanga biodiesel and optimization using Taguchi method," Process Safety and Environmental Protection, vol. 120, pp. 146-154, 2018.

[31] Z.Ö. Özdemir ve H. Mutlubaş, "Biyodizel üretim yöntemleri ve çevresel etkileri," Kırklareli University Journal of Engineering and Science, s. 2, ss. 129-143, 2016.

[32] S. İzgiz, Deney Tasarımı ve Taguchi Metodu - Ürün ve Proseslerin Optimizasyonu, 1. bask1, Kocaeli, Türkiye: Federal Mogul, 1999, böl. 5, ss. 87-110.

[33] M. Şirvanc1, Kalite İçin Deney Tasarımı, 1. baskı, İstanbul, Türkiye: Literatür Yayınc1lık, 1997, böl. 1, ss. 11-16.

[34] R. Behçet ve F. Oral, "Dizel motor performans ve emisyonları üzerindeki biyodizel-dizel karışım yakıtların etkisi,” Bitlis Eren Üniversitesi Fen Bilimleri Dergisi, c. 3, s. 1, ss. 15-23, 2014.

[35] A.N. Özsezen ve M. Çanakçı, "Biyodizel ve karışımlarının kullanıldığ bir dizel motorda performans ve emisyon analizi," Pamukkale Üniversitesi Mühendislik Bilimleri Dergisi, c. 15, s. 2, ss. 173-180, 2009.

[36] A. Jamrozik, "The effect of the alcohol content in the fuel mixture on the performance and emissions of a direct injection diesel engine fueled with diesel-methanol and diesel-ethanol blends," Energy Conversion and Management, vol. 148, pp. 461-476, 2017.

[37] E. Turgut, G. Çakmak and C. Y1ldı, "Optimization of the concentric heat exchanger with injector turbulators by Taguchi method," Energy Conversion and Management, vol. 53, pp. 268-275, 2012. 